\title{
Sheep urinary tract architecture is not affected by acute urethral obstruction
}

\section{A arquitetura do trato urinário de ovinos não é afetada pela obstrução uretral aguda}

\author{
Thiago Arcoverde Maciel ${ }^{1 *}$; Clédson Calixto de Oliveira ${ }^{2}$; Millena de Oliveira \\ Firmino ${ }^{3}$; Lismara Castro do Nascimento-Hama4; Luis Antonio Mathias ${ }^{5}$; Silvana \\ Martinez Baraldi Artoni6; Daniela Oliveira7; Lizandra Amoroso ${ }^{6}$
}

\section{Highlights}

Rich grain diets is frequently offered over a prolonged period in sheep farming.

Kidney multifocal areas present alterations such as acute glomerular tuft congestion.

Diet and subsequent alterations predispose the development of acute urolithiasis.

\begin{abstract}
Urolithiasis affects the urinary tract of small ruminants, thereby requiring the animal to prematurely terminate breeding. Morphometric study of organs can be used as a diagnostic method. Thus, this study aimed to describe the macroscopic, histopathological, and histomorphometric changes in the urinary tract of sheep with urolithiasis. For this purpose, 14 healthy male Santa Inês sheep, approximately 90 days old, were studied and fed an experimental diet. After the development of urolithiasis, the animals were reorganized into two groups, D1 (without urolithiasis) and D2 (with urolithiasis) for comparative data analysis. Sheep were necropsied to evaluate the pathological changes, followed by macroscopic morphometric analysis, and the histopathological and histomorphometric characteristics were described. Urethral necrosis and a full urinary bladder were observed in all animals that developed the disease. The comparison between sheep with and

1 Prof. Dr. of the Academic Unit of Veterinary Medicine, Federal University of Campina Grande, UFCG, Patos, PB, Brazil. E-mail: arcoverde.thiago@hotmail.com

2 Resident of the Multidisciplinary Residency Program in Clinic and Surgery for Large Animals at the Veterinary Hospital of UFCG / Patos, UFCG, Patos, PB, Brazil. E-mail: cledsonvet@gmail.com

3 Student of the Doctorate of the Graduate Program in Veterinary Medicine, Laboratory of Animal Pathology UFCG / Patos UFCG, Patos, PB, Brazil. E-mail: millena_deoliveira@yahoo.com.br

4 Student of the Doctorate of the Post-Graduate Program in Veterinary Medicine, Paulista State University "Júlio de Mesquita Filho", UNESP, Jaboticabal, Jaboticabal, SP, Brazil. E-mail: lismarajf@outlook.com

5 Prof. Dr. from the Department of Preventive Veterinary Medicine and Animal Reproduction, UNESP, Jaboticabal, Jaboticabal, SP, Brazil. E-mail: la.mathias@unesp.br

6 Profas Dras of the Department of Animal Morphology and Physiology, UNESP, Jaboticabal, Jaboticabal, SP, Brazil. E-mail: silvana.artoni@unesp.br; lizandra.amoroso@gmail.com

7 Profa. Dra, Department of Animal Anatomy, Academic Unit of Garanhuns, Federal Rural University of Pernambuco, UAG / UFRPE, Garanhuns, PE, Brazil. E-mail: danisjc6@yahoo.com.br

* Author for correspondence
\end{abstract}

Received: Nov. 29, 2019 - Approved: Feb. 06, 2021 
without urolithiasis showed no significant difference $(P<0.05)$ in the evaluated macroscopic morphometric variables, except for the right ureter width. Regarding the histopathological evaluation, multifocal areas of mild to moderate congestion within the glomerular tufts and protein in the tubular lumen of the kidneys were observed. In the liver, mild to moderate fatty degeneration was noted in the centrolobular regions, and an ulcerated focal area in the bladder mucosa was observed in only one animal. The present study demonstrated that the formulated diet was effective in inducing clinical disease. In acute obstructive urolithiasis in sheep tissue, lesions in the liver and urinary tract were observed, although there were no significant histomorphometric changes.

Key words: Histopathology. Hydronephrosis. Morphometry. Ram. Urolith.

\section{Resumo}

Urolitíase acomete o trato urinário de pequenos ruminantes causando a saída prematura de animais destinados à reprodução. O estudo morfométrico dos órgãos pode ser empregado como método de auxílio diagnóstico. Assim, este estudo objetivou descrever as alterações macroscópicas, histopatológicas e histomorfométricas do trato urinário de ovinos com urolitíase. Com esse fim, foram utilizados 14 ovinos hígidos, machos, da raça Santa Inês com idade aproximada de 90 dias, que receberam dieta experimental. Após o desenvolvimento da urolitíase os animais foram reorganizados em dois grupos experimentais distintos D1 (sem urolitíase) e D2 (com urolitíase) para a análise comparada dos dados. Os ovinos foram necropsiados para descrição das alterações patológicas, seguindo-se a análise morfométrica macroscópica e descrição quanto as características histopatológicas e histomorfométricas. Necrose de processo uretral e bexiga urinária repleta foram observados em todos os animais que desenvolveram a doença. Na comparação entre os ovinos com e sem urolitíase não houve diferença significativa $(P<0,05)$ nas variáveis morfométricas macroscópicas avaliadas, a exceção da largura do ureter direito. Quanto à avaliação histopatológica, foram observadas áreas multifocais de discreta a moderada congestão dos tufos glomerulares e proteína no lúmen tubular nos rins. No fígado, observou-se nas regiões centrolobulares, discreta a moderada degeneração gordurosa e apenas em um animal foi observada, macro e microscopicamente, área focal ulcerada na mucosa da bexiga. Os achados da presente pesquisa demonstraram que a dieta formulada foi eficaz na indução da doença clínica. Na urolitíase obstrutiva aguda em ovinos, lesões teciduais em fígado e trato urinário são observadas, mas não há alterações histomorfométricas significativas.

Palavras-chave: Histopatologia. Hidronefrose. Morfometria. Carneiro. Urólito.

\section{Introduction}

Obstructive urolithiasis is the most economically important urinary tract disease in sheep breeding because it has a high mortality rate (Ortolani, 1996; Afonso \& Guaraná, 2008). Guimarães et al. (2012) reported lethality of $69.70 \%$ and $30.30 \%$ for animals with total and partial obstruction, respectively.
Although the processes involved in biomineralization are not fully elucidated, it is known that the formation of uroliths results from the interaction of numerous common factors between ruminants reared in production systems, such as anatomy, physiology, nutrition (Smith \& Sherman, 1994; Belknap \& Pugh, 2002), animal species, and sex (Dória, Canola, Dias, Pereira, \& Valadão, 2007). 
These factors are associated with low water consumption, which saturates the urine and favors the precipitation and crystallization of solutes (Radostits, Gay, Hinchcliff, \& Constable, 2007).

The chemical composition of the urolith is directly related to the diet, and the formation of struvite (ammonium magnesium phosphate) and apatite (calcium phosphate) crystals are commonly reported in animals treated with high-grain diets (Sun, Wang, Zhang, \& Wang, 2010; Pan et al., 2011). Calcium tartrate uroliths, calcium citrate, hydrated sodium oxalate, and hydrated potassium oxylate can also be found (Maciel et al., 2016).

One technique that has been employed to assist in the diagnosis of some diseases is morphometric analysis (Rech et al., 2006; Duarte et al., 2007; Pagnano et al., 2008). In vivo, morphometric parameters can be analyzed by complementary examinations that help with diagnosis and possible prognosis, such as radiographic and ultrasound images, which reveal when there is an increase or decrease in size or radiolucency and echogenicity changes in a given organ or tissue (Campos et al., 2013).

Different researchers have described morphometric changes in the urinary tract of sick animals. Lima et al. (2009) and Martins et al. (2013) reported dilated ureters and increased renal volume in cats with lower urinary tract disease. Gooneratne, Howell and Aughey (1986) stated that glomerular and tubular damage is proportional to the degree of hemolysis in copper-poisoned sheep. Farrugia et al. (2006) reported basal urothelium apoptosis in sheep fetuses after 30 days of urethral and urachal obstruction. Lu et al. (2017) observed that reduced storage capacity and bladder emptying ability are a consequence of bladder fibrosis in urinary tract obstructions. These descriptions demonstrate the importance of knowledge and pathological and histomorphometric analysis in the clinical routine.

Considering the relevance of this disease in sheep, the purpose of the present study was to verify the effect of a phosphorusrich hyperproteic diet on the development of obstructive urolithiasis. Thus, the macroscopic, pathological, and histomorphometric changes in the urinary tract of male Santa Inês sheep with obstructive urolithiasis were described and compared to those of healthy animals to contribute to the understanding of the disease.

\section{Materials and Methods}

\section{Approval of the ethics committee}

All methodologies adopted for the development of the present research were submitted and approved by the Ethics Committee on the Use of Animals (CEUA) of the Federal Rural University of Pernambuco (UFRPE), Recife-PE, under protocol number 13726 / 2012-97.

Study site and animal selection and management

The animals were confined in an experimental pen for small ruminants in the Academic Unit of Garanhuns (UAG), Rural Federal University of Pernambuco (UFRPE) in individual stalls $(2.0 \mathrm{~m} \times 1.0 \mathrm{~m}$, masonry) throughout the trial period. Natural source water was supplied through plastic containers to measure daily consumption. 
Fourteen healthy Santa Ines male sheep (non-castrated), aged approximately 90 days and weighing $23.13 \pm 4.08 \mathrm{~kg}$, were utilized. Prior to the beginning of the experiment, a fecal parasitological examination along with endoparasite control with oral sulfaquinoxaline and Closantel sodium (Sulfaquinoxalina@ Vansil and Diantel $^{\odot}$ 10\%) and a clostridial vaccination (Poli-Star ${ }^{\odot}$ Valle, São Paulo, SP, Brazil) were performed. The pre-experimental phase for adaptation of the rumen microbiota was 15 days, in which all animals received the same balanced diet. Subsequently, there was a gradual daily reduction in the ratio of roughage/concentrate until a proportion of $30 \%$ roughage and $70 \%$ concentrate was reached and maintained until the end of the experiment.

\section{Experimental design}

The animals were fed for 90 days with feed consisting of Tifton 85 crushed hay ( $3 \mathrm{~cm}$ fiber), a mixture of ground corn and soybean meal, and anhydrous dibasic sodium phosphate P.A. and Tortuga commercial salt (Ovinofós ${ }^{\odot}$ ). The resultant mixture contained a $\mathrm{Ca} / \mathrm{P}$ imbalance (1:2) and a 30:70 forage/ concentrate ratio (Table 1). After this initial period, the animals received a new diet with an increased Ca/P ratio (1:3) for 29 days.

The total ration was fed fractionally between two feeding times, 8 and 14 h, in plastic troughs with dimensions of $50 \times 20 \times$ $30 \mathrm{~cm}$, and the remnants were weighed daily to determine consumption.

For experimental safety, the total ration was subjected to bromatological analysis, and water was submitted for chemical analysis.

\section{Table 1}

Chemical and calculated composition of experimental diets

\begin{tabular}{|ccc|}
\hline Ingredient & $\begin{array}{c}\text { Pre-experimental diet } \\
\text { (g/kg of DM) }\end{array}$ & $\begin{array}{c}\text { Calculogenic diet (g/kg of DM) } \\
\text { Ca / P ratio (unbalanced) }\end{array}$ \\
\hline Tifton85 hay & 700.00 & 300.00 \\
\hline Ground corn & 180.50 & 560.70 \\
\hline Soybean meal & 100.00 & 96.00 \\
\hline Anhydrous dibasic sodium phosphate & - & 22.00 \\
\hline Mineral supplement * & 15.00 & 15.00 \\
\hline Chemical composition & & 860.94 \\
\hline Dry matter (g / kg DM) & 860.57 & 121.36 \\
\hline Crude protein (g / kg DM) & 121.79 & 2,774 \\
\hline Metabolizable Energy (kcal) & 2,446 & 45.58 \\
\hline Ether extract (g / kg DM) & 34.00 & 4.16 \\
\hline Calcium (g / kg DM) & 5.67 & 8.38 \\
\hline Phosphorus (g / kg DM) & 2.95 & \\
\hline
\end{tabular}

Note. * Ovinofós ${ }^{\circledR}$ Mineral Salt: Zinc (3,800.00 mg), Sodium (147.00g), Manganese (1,300.00 mg), Cobalt (40.00 mg), Iron (1,800.00 mg), Copper (590.00 mg) Sulfur (18.00 g), Selenium (15.00 mg), lodine (80.00 mg), Chromium (20.00 mg), Molybdenum (300.00 mg), Calcium (120.00 g), Fluorine (max) (870.00 mg), Phosphorus (87.00 g). 
The total confinement period (119 days) was established in this experiment to ensure sufficient time and conditions for urolith formation and development of obstructive urolithiasis (Figure 1). After the end of the experiment, the animals were reorganized, forming two distinct experimental groups, D1 (without urolithiasis) and D2 (with urolithiasis), for comparative analysis of the data. The average total feed intake was $6.01 \%$ of live weight; at the end of the experiment the animals weighed $36.12 \pm 7.02 \mathrm{~kg}$, and the average weight gain and standard deviation per group was $0.11 \pm 0.04 \mathrm{~kg}$ and $0.14 \pm 0.05$ $\mathrm{kg}$, respectively.

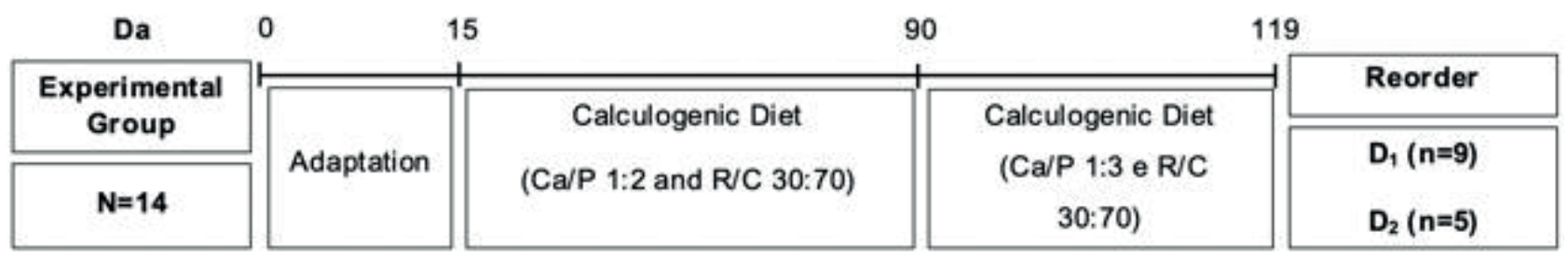

Figure 1. Experimental design scheme.

Ca - Calcium; C - concentrate; D1 - (Without urolithiasis); D2 - (With urolithiasis); P - Phosphorus; $\mathrm{R}$ - Roughage.

Harvesting and analysis

Sheep were examined every 7 days throughout the experimental period, following the technique described by Dirksen, Gründer and Stöber (1993). Immediately after clinical confirmation of the development of obstructive urolithiasis, the affected sheep were slaughtered according to the current legislation for the species and necropsied.

Macroscopic necropsy findings were photo-documented and described. Bilateral morphometric analysis of the kidneys was performed with the aid of a digital caliper (Mastercraft ${ }^{\circledR}$ ) measuring the length (distance between cranial and caudal poles), thickness (dorsoventral distance of the mid portion of the organ), and width (distance from the medial to the lateral margin), in addition to the thickness of the renal cortex and medulla.
The ureters were measured for width and length (from the renal hilum to urinary bladder insertion, excluding the intramural region). For the urethral process, the length was recorded, taken from its insertion to the apex. The ureter width and the urethral process length were measured with a digital caliper (Mastercraft ${ }^{\circledR}$ ) and the ureter length with a common millimeter ruler.

For histopathological and histomorphometric analysis, $2 \mathrm{~cm}$ samples from the liver (right and left hepatic lobes), kidneys (longitudinal section involving cortical and medullary region), and urinary bladder (bladderneck-bladdertrigoneandadjacencies) were fixed in buffered formaldehyde $10 \%$ and underwent the histological routine. After $48 \mathrm{~h}$, the samples were dehydrated in a progressive series of ethanol, diaphanized with xylol, and impregnated with paraffin. Serial $5 \mu \mathrm{m}$ 
sections were then prepared, and the slides were stained with hematoxylin and eosin (HE) (Tolosa, Rodrigues, Behmer, \& Freitas, 2003). Histological slides were observed on $4 \times, 20 x$, and $40 x$ objective lenses using an Olympus binocular photomicroscope, and the changes were documented and described. Subsequently, the diameter of the renal corpuscles and hepatocytes was measured, and the hepatocyte count per field was determined using Olympus software (Cell Sens 1.14). The nomenclature used is in accordance with the Nomina Anatomica Veterinaria (International Committee on Veterinary Gross Anatomical Nomenclature [ICVGAN], 2017).

\section{Statistical analysis}

For macroscopic morphometry, the data were analyzed with the computer program Statistical Analysis System [SAS] (2009), using the GLM procedure. For all statistical analyses, a significance level $(P)$ of $5 \%$ was adopted. In cases in which there was significance in the $\mathrm{F}$ test, the means were compared by the minimum significant difference (msd) of the SNK test.

For histomorphometry, data from each group were subjected to the Shapiro-Wilk normality test. With normality $(P>0.05)$, the two groups were compared via parametric tests. Initially, the variances were compared using the $F$ test. If equality of variances occurred $(P$ $>0.05)$, the two groups were compared using a t-test; if not, the groups were compared using the Welch test. When data were not normal, the comparison was made by the Wilcoxon rank sum test. Differences were considered significant when $\mathrm{P}<0.05$. Analyses were performed using $\mathrm{R}$ software.

\section{Results and Discussion}

Physical examination confirmed the health of all sheep at the beginning of the experiment, which remained active and fed normally during the experimental period. Over time, fecal changes from solid to pasty were observed in all sheep. Pugh (2002) attributed this change to ruminal acidosis caused by diets with a high percentage of fermentable carbohydrates and starchy foods (cereal grains, wheat, oats, corn, and sorghum).

The first case of obstructive urolithiasis occurred 56 days after the start of the experiment. Five out of 14 animals presented with total obstructive urolithiasis, verifying the calculogenic potential of the formulated diet; however, approximately $64 \%$ of sheep did not develop the disease. This was probably due to high water consumption, which minimizes urine saturation and salt precipitation (Radostits et al., 2007; Tiruneh, 2006). Furthermore, the change in diet, from the initial levels of calcium/ phosphorus in the ratio $1: 2$ to $1: 3$, may have favored the adaptation of ruminal microbiota to the calculogenic diet, optimizing phosphorus metabolism. Additionally, individual and/or genetic factors may have contributed to the absence of urolithiasis development in these animals.

The sheep that manifested the disease presented several typical clinical signs, including apathy or restlessness, stranguria, abdominal contraction and kicking with exposure and licking of the penis, postural changes (arching of the back, abduction of the pelvic limbs, and raised tail), congested glans, and urethral process with areas of necrosis and firm to palpation, as well as discomfort and sensitivity at the examination of the urogenital 
tract. There were more exacerbated signs in one of the animals that presented with urethral rupture. These signs were not observed by Santarosa et al. (2016), although the animals in their experiment were confined for 56 days, a time sufficient for urolith development. They were found during necropsy exclusively in the renal pelvis, without causing obstruction. Therefore, the authors reported the absence of signs, such as dysuria, urethral obstruction, or bladder rupture. Ferreira (2009, 2013) correlated this absence of signals in confined lambs for slaughter to the short time of termination, which, after weaning around 60 days, lasts for an average of 39 days.

Penile urethral rupture occurred in only one animal, which presented with anuria, edema, and sensitivity to palpation of the ventroabdominal region (scrotal region to xiphoid cartilage) and swollen foreskin preventing penile exposure, as well as vocalization, bruxism, and digging movements. The same signs were observed in $27.4 \%$ of sheep and goats studied by Morais (2012). Hay and Suttle (1991) and Riet-Correa, Simões and Vasconcelos, (2008) stated that in cases of urethral necrosis and bladder rupture, leakage of urine into the connective tissue of the ventral abdominal wall and prepuce or abdominal cavity cause edema, tissue irritation, necrosis, urine resorption, and uremia.

The main necropsy findings of the affected animals were a full bladder with extensive area of hemorrhage, necrosis of the urethral process, and dilation of the ureter and renal pelvis (Figure 2), as reported by Lima et al. (2009). Santarosa et al. (2016) observed hydronephrosis and unilateral dilatation of the ureter in only one sheep without presenting clinical pain symptoms. 

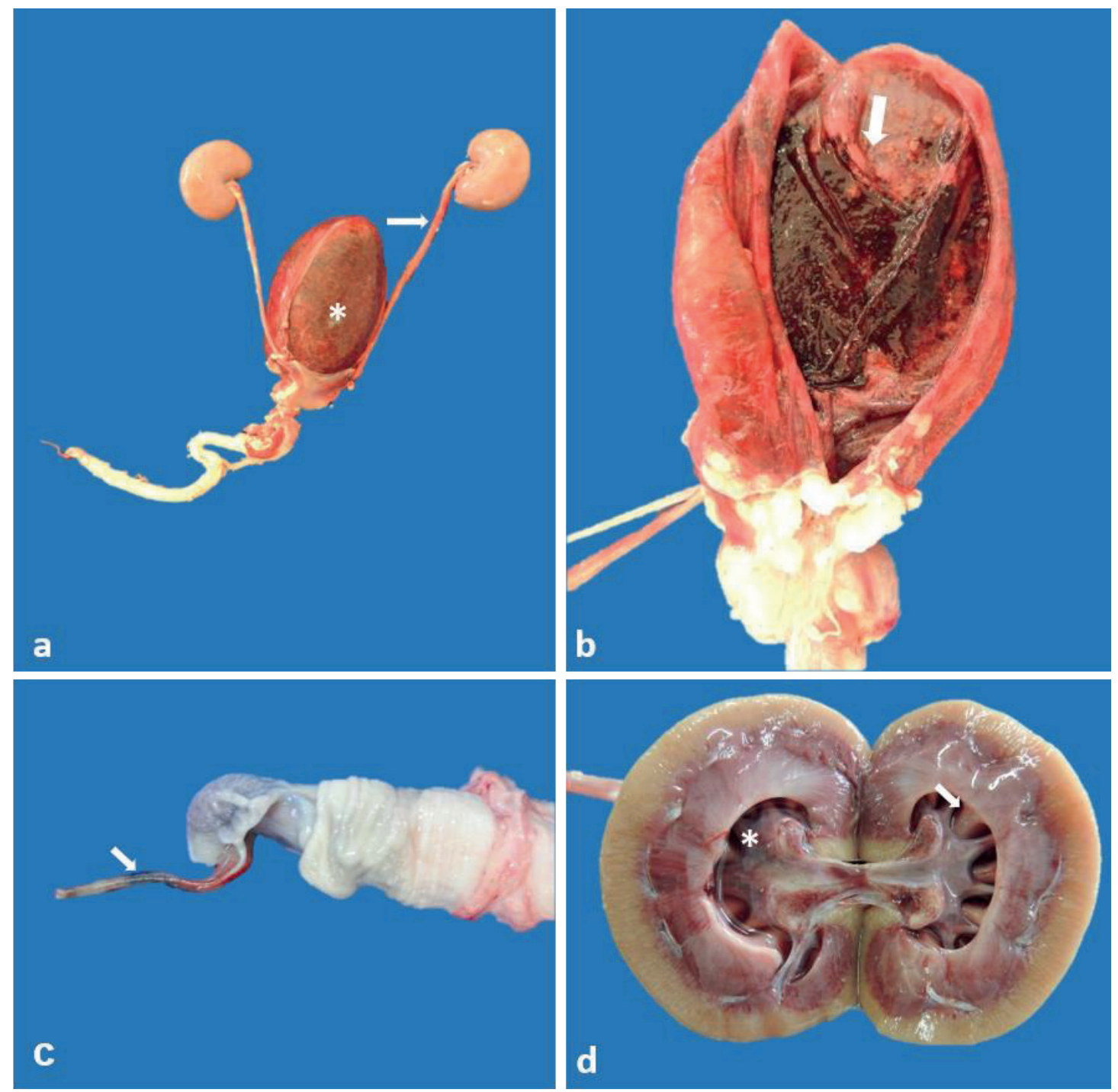

Figure 2. Necropsy findings of sheep with obstructive urolithiasis.

(a) Panoramic view of the urinary tract. It is observed discreetly dilated ureter (arrow) and markedly distended urinary bladder (*). (b) Urinary bladder at longitudinal section. Marked necrohemorrhagic cystitis (arrow) was noticed in the body of urinary bladder. (c) Urethral process with extensive area of necrosis and hemorrhage (arrow). (d) Hydronephrosis, characterized by moderate dilation of the renal pelvis $(*)$ and evidence of renal chalices (seta).

Uroliths were mostly deposited in the urinary bladder, although they were also found in the renal pelvis and urethra, especially in the sigmoid flexure and the urethral process, the main obstruction points (Figure 3). Santarosa et al. (2016) reported sandy aspect calcifications exclusively in the kidneys, whereas Assis et al. (2009) observed uroliths mainly in the right kidney and in the bladder outlet to the urethra and sigmoid flexure. Such findings are frequent, and their severity is directly related to the clinical evolution of the condition and the degree of obstruction. 

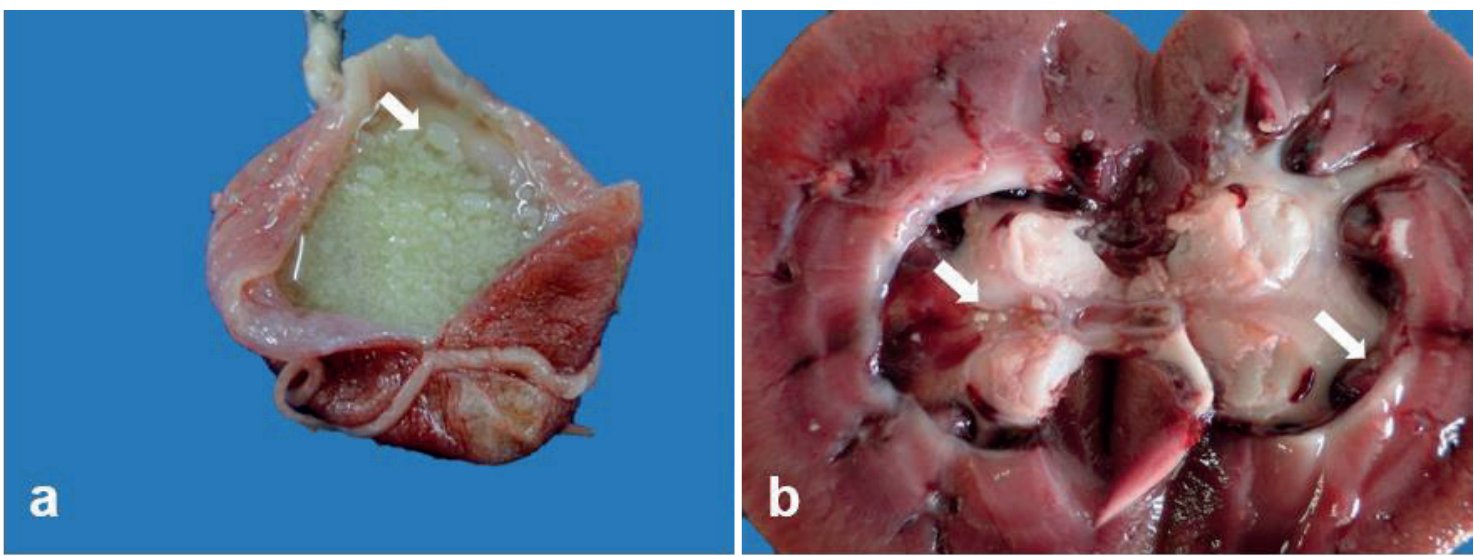

Figure 3. Urinary bladder and kidney of sheep treated with a calculogenic diet.

(a) Urinary bladder full of irregular yellowish-white uroliths (arrow). (b) Kidney. Irregular yellowishwhite uroliths are observed in renal pelvis (arrows).

In addition to the lesions described above, one of the animals presented with a urethral rupture. In the region of the penile path, there was a large reddish and gelatinous area characteristic of edema. The dissection revealed a ruptured area containing compacted mineral content completely obstructing the urethral lumen (Figure 4), as previously described by Radostits et al. (2007) and Assis et al. (2009).

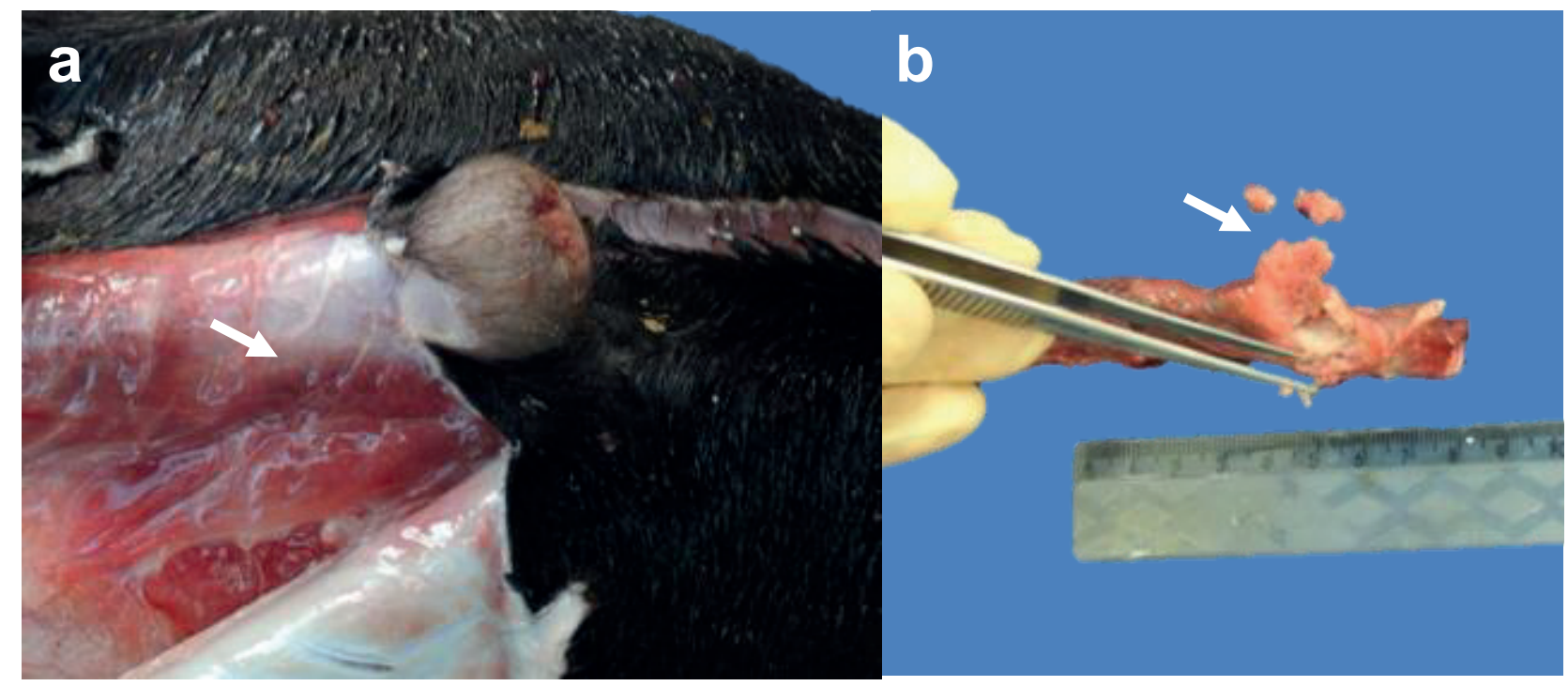

Figure 4. Necropsy findings of sheep fed a calculogenic diet with ruptured urethra.

(a) Subcutaneous edema around the foreskin, characterized by deposition of slightly reddish gelatinous material (arrow). (b) Urethral rupture with compressed mineral content (arrow). 
Although not correlated with urolithiasis, a more cranial anatomical position of the right kidney reflected significantly higher averages for right ureters $(P<0.05)$ compared to the normal condition of the left ureters, as reported by Dyce, Sack and Wensing (2010) Rossi, Bombonato, Piva and Gregory (2012) evaluated the renal morphometry of healthy goats by ultrasonography and confirmed the cranial position of the right kidney.

Comparison of sheep that developed urolithiasis with those without the disease showed no significant difference in the macroscopic morphometric variables evaluated, except for the right ureter width. Although D2 animals presented higher values for length, width, and thickness of kidneys, there was no statistical difference between the groups (Table 2). Some of these data corroborate the report by Assumção, PereiraSampaio, Sampaio and Souza (2018), who observed increased renal volume, weight, and cortical volume in rats subjected to contralateral nephrectomy after $24 \mathrm{~h}$ of ureter obstruction. However, the hypertrophic response did not occur when the obstructed kidney or ureter was not removed. These authors concluded that the lack of a kidney is less harmful to the contralateral organ than a blocked kidney or ureter. Sisson and Grossman (1986) reported a length of $7.5 \mathrm{~cm}$ and a width of $5 \mathrm{~cm}$ in the kidneys of this species, which are numerically higher than those found in this study, which may reflect the breed, size, and age of the evaluated animals.

Table 2

Analysis of variance and mean values \pm standard deviation of morphometry $(\mathrm{mm})$ of Santa Inês sheep kidneys $(n=14)$

\begin{tabular}{|c|c|c|c|c|c|c|c|c|c|c|}
\hline \multirow[b]{2}{*}{ Groups } & \multicolumn{5}{|c|}{ Right kidney } & \multicolumn{5}{|c|}{ Left kidney } \\
\hline & Length & Width & $\begin{array}{l}\text { Thick- } \\
\text { ness }\end{array}$ & $\begin{array}{l}\text { Cortex } \\
\text { height }\end{array}$ & $\begin{array}{c}\text { Medulla } \\
\text { height }\end{array}$ & Length & width & $\begin{array}{l}\text { thick- } \\
\text { ness }\end{array}$ & $\begin{array}{l}\text { Cortex } \\
\text { height }\end{array}$ & $\begin{array}{c}\text { Medulla } \\
\text { height }\end{array}$ \\
\hline $\mathrm{D}_{1}$ & $\begin{array}{l}63.31 \\
\pm 3.61\end{array}$ & $\begin{array}{l}40.73 \\
\pm 5.77\end{array}$ & $\begin{array}{l}35.64 \\
\pm 7.41\end{array}$ & $\begin{aligned} & 8.8 \\
\pm & 0.90\end{aligned}$ & $\begin{array}{r}17.55 \\
\pm 1.80\end{array}$ & $\begin{array}{r}63.99 \\
\pm 3.92\end{array}$ & $\begin{array}{l}42.36 \\
\pm 5.53\end{array}$ & $\begin{array}{l}32.86 \\
\pm 5.07\end{array}$ & $\begin{array}{c}8.32 \\
\pm 0.88\end{array}$ & $\begin{array}{r}16.74 \\
\pm 1.79\end{array}$ \\
\hline $\mathrm{D}_{2}$ & $\begin{array}{l}65.00 \\
\pm 7.16\end{array}$ & $\begin{array}{l}46.15 \\
\pm 6.38\end{array}$ & $\begin{array}{l}36.03 \\
\pm 8.90\end{array}$ & $\begin{array}{c}8.39 \\
\pm 1.28\end{array}$ & $\begin{array}{r}17.50 \\
\pm 3.50\end{array}$ & $\begin{array}{l}68.72 \\
\pm 6.60\end{array}$ & $\begin{array}{l}47.27 \\
\pm 6.52\end{array}$ & $\begin{array}{l}35.00 \\
\pm 7.55\end{array}$ & $\begin{array}{c}8.48 \\
\pm 1.72\end{array}$ & $\begin{array}{r}17.50 \\
\pm 2.69\end{array}$ \\
\hline P (length var) & 0.09 & 0.75 & 0.61 & 0.37 & 0.10 & 0.20 & 0.64 & 0.31 & 0.10 & 0.30 \\
\hline $\mathrm{P}$ (t / Welch test) & 0.56 & 0.13 & 0.93 & 0.50 & 0.97 & 0.11 & 0.16 & 0.53 & 0.82 & 0.53 \\
\hline $\begin{array}{l}\mathrm{P} \text { (Nonpara- } \\
\text { metric Test) }\end{array}$ & - & - & 1.0 & - & - & - & 0.30 & 0.44 & - & - \\
\hline
\end{tabular}

Note. - There was no significant difference $(P<0.05)$ in the comparison between groups. $D_{1}-$ without urolithiasis $(n=9)$ $D_{2}$ - with urolithiasis $(n=5)$.

Sheep that developed urolithiasis (D2) presented with larger ureter widths compared to those of the other group (D1), but the only statistical difference occurred for the right ureter, which may have contributed to less stone retention at this site (Table 3). These data are consistent with those described by Santarosa et al. (2016), who observed unilateral 
dilatation of the ureter, and Lima et al. (2009), who reported dilated ureters and increased renal volume in domestic cats with lower urinary tract disease, a finding also observed by Martins et al. (2013) when performing image analysis on animals with the same disease. Newman, Confer and Panciera (2009) verified that ureter dilation and hydronephrosis occur as a result of the delay between the clinical manifestation of the first signs of urolithiasis and slaughter. Faria et al. (2011) also observed right ureter and right kidney dilation in dogs with hydronephrosis and pyonephrosis caused by chronic urethral obstruction.

Table 3

Analysis of variance and mean values \pm standard deviation of length $(\mathrm{cm})$ and width $(\mathrm{mm})$ of ureters and length $(\mathrm{cm})$ of urethral process of Santa Inês sheep $(n=14)$

\begin{tabular}{|cccccc|} 
& \multicolumn{2}{c}{ Right ureter } & \multicolumn{2}{c}{ Left ureter } & Urethral process \\
Groups & Length & width & Length & width & length \\
\hline $\mathrm{D}_{1}$ & $25.50 \pm 2.70$ & $2.71 \pm 0.56$ & $22.5 \pm 2.87$ & $2.95 \pm 1.15$ & $4.10 \pm 0.51$ \\
$\mathrm{D}_{2}$ & $26.75 \pm 1.26$ & $3.55 \pm 2.53$ & $22.5 \pm 1.29$ & $3.34 \pm 1.65$ & $3.96 \pm 0.45$ \\
$\mathrm{P}$ (length var) & 0.24 & $0.0006^{*}$ & 0.22 & 0.36 & 0.87 \\
$\mathrm{P}$ (t / Welch test) & 0.40 & 0.50 & 1.0 & 0.61 & 0.63 \\
$\mathrm{P}$ (nonparametric test) & - & 1.0 & - & 0.89 & -
\end{tabular}

Note. - $\left(^{*}\right)$ - significant difference between groups $(P<0.05)$. $D_{1}$ - without urolithiasis $(n=9) D_{2}$ - with urolithiasis $(n=)$.

Regarding the length of the urethral process, there was no statistical difference between the studied groups. It is common in sheep urolithiasis that obstruction of the urethral process progresses to necrosis (Maciel et al., 2017), for which amputation is a treatment option. However, there is a high chance of stenosis beyond urethrostomy and penectomy (Sousa et al., 2011).

Histopathological examination of the kidneys of three animals showed vascular lesions of inflammatory nature, such as discrete multifocal infiltrates of lymphocytes, plasma cells, and macrophages in the medular region; discrete to moderate congestion of multifocal areas of the glomerular tufts, located mainly in the medullar region; and mild presence of protein in the tubular lumen. Nevertheless,
Santarosa et al. (2016) described renal vascular congestion with mild and moderate presence of protein in the lumen tube in sheep urolithiasis. According to Frelier, Armstrong and Pritchard (1990) and Garcia-Navarro (2005), the presence of protein in the tubular lumen occurs due to lower resorption capacity, indicating tubular lesions, whereas post-renal proteinuria characterizes glomerular disease.

In the liver, in the centrolobular regions, mild to moderate fatty degeneration was observed, characterized by the presence of large and unique vacuoles in the hepatocyte cytoplasm (Figure 5). In the left lobe of the liver, fatty degeneration was higher in group $D_{1}(P<0.05)$. In one animal, mild multifocal inflammation with random hepatocyte necrosis was observed. According to Aroeira 
(1998) and Jones, Hunt and King (2000), fat accumulation occurs as a consequence of the imbalance between the uptake of fatty acids by the liver and its utilization capacity. Souza (2003) highlighted fat cow syndrome, cattle ketosis, and pregnancy toxemia in beef cows, sheep, and goats as the main diseases causing lipidosis, reinforcing that husbandry with the provision of hypercaloric diets favors the development of this disease.
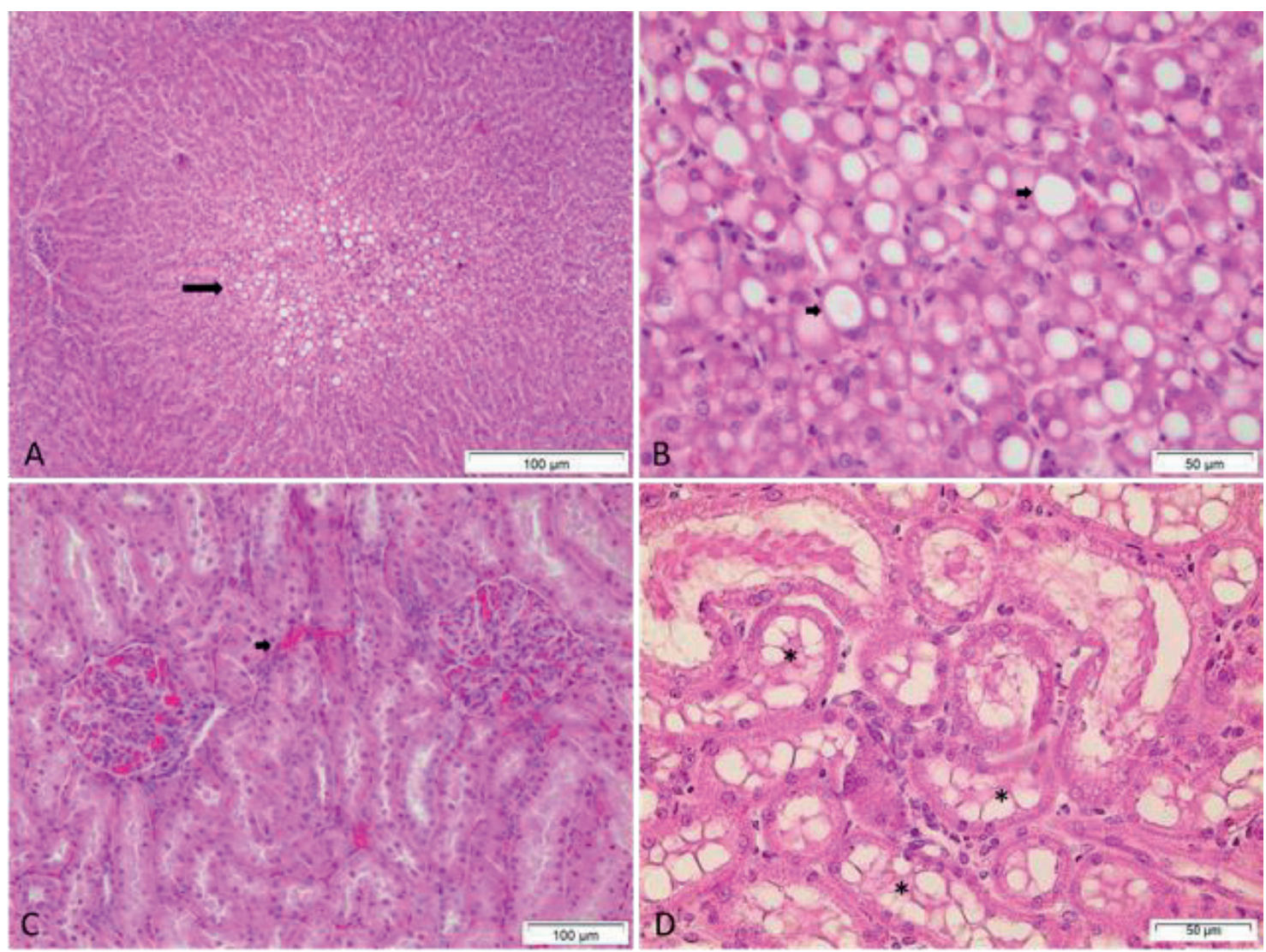

Figure 5. Photomicrographs of liver and kidney of sheeps with experimental urolithiasis.

A) Mild fatty degeneration is observed in the centrolobular region (arrow) in the liver. $\mathrm{HE}$. Bar = $100 \mu \mathrm{m}$. B) Large and unique, well-defined vacuoles (arrows) in the cytoplasm of hepatocytes characteristic of hepatic fatty degeneration. $\mathrm{HE}$. Bar $=50 \mu \mathrm{m}$. C) Mild congestion in the glomerular tufts (large arrow) and blood vessels in the cortical region of the kidney (small arrow). HE. Bar $=100$ $\mu \mathrm{m}$. D) Renal intratubular protein deposition (*). HE. Bar $=100 \mu \mathrm{m}$.

The other histological morphometric variables did not differ statistically between the groups, nor between the animals that developed urolithiasis and those that did not (Table 4). 
Table 4

Renal and hepatic histomorphometric data of Santa Inês sheep $(n=14)$

\begin{tabular}{|cccccc|}
\hline Variable & $\begin{array}{c}\text { Without } \\
\text { urolithiasis } \\
\left(\mathrm{D}_{1} \mathrm{n}=9\right)\end{array}$ & $\begin{array}{c}\text { Urolithiasis } \\
\left(\mathrm{D}_{2} \mathrm{n}=5\right)\end{array}$ & $\begin{array}{c}\mathrm{P} \text { (lenght } \\
\text { var) }\end{array}$ & $\begin{array}{c}\mathrm{P} \text { (t / Welch } \\
\text { test) }\end{array}$ & $\begin{array}{c}\mathrm{P} \text { (nonpara- } \\
\text { metric test) }\end{array}$ \\
\hline Centrolobular Fatty Degeneration RL & $1.22 \pm 1.09$ & $1.2 \pm 1.30$ & 0.621 & 0.973 & - \\
\hline RL Degeneration Distribution & $1.67 \pm 1.41$ & $1.6 \pm 1.52$ & 0.800 & 0.936 & 0.943 \\
\hline RL congestion & $0.56 \pm 0.53$ & 0 & - & - & 0.0545 \\
\hline Centrolobular Fatty Degeneration LL & $1.22 \pm 1.09$ & $1.67 \pm 1.53$ & 0.408 & 0.588 & - \\
\hline LL Degeneration Distribution & $1.67 \pm 1.41$ & $2 \pm 1.73$ & 0.560 & 0.743 & 0.763 \\
\hline LL congestion & $0.56 \pm 0.53$ & 0 & $2.2 \mathrm{e}-16$ & 0.013 & 0.131 \\
\hline Cortical Congestion R Kidney & $0.22 \pm 0.44$ & 0 & $2.2 \mathrm{e}-16$ & 0.169 & 0.323 \\
\hline Spinal Cord Congestion R Kidney & $1.78 \pm 0.97$ & $0.8 \pm 0.84$ & 0.820 & 0.084 & - \\
\hline Intratubular Protein R Kidney & $1 \pm 0.5$ & $1.2 \pm 0.45$ & 0.884 & 0.472 & 0.515 \\
\hline Cortical Congestion L Kidney & $0.22 \pm 0.44$ & 0 & $2.2 \mathrm{e}-16$ & 0.290 & 0.323 \\
Spinal Cord Congestion L Kidney & $1.56 \pm 0.88$ & $1 \pm 0.71$ & 0.706 & 0.252 & - \\
Intratubular Protein L Kidney & $1 \pm 0.5$ & $1.4 \pm 0.89$ & 0.152 & 0.297 & -
\end{tabular}

Note. - There was no significant difference $(P<0.05)$ in the comparison between groups. $D_{1}-$ without urolithiasis $(n=9) D_{2}$ - with urolithiasis ( $n=5)$. R - Right. L - Left. RL - Right Lobe. LL - Left Lobe. Congestion: Absent (0), Discreet (1), Moderate (2), Severe. Intratubular Protein: Absence (0), Discrete (1), Moderate (2). Centrolobular Fat Degeneration: Absent (0), Discrete (1), Moderate (2), Severe (3). Degeneration Distribution: Absent (0), Focal (1), Multifocal (2), Diffuse (3).

No histological changes were observed in the liver and kidneys with regard to morphometry (quantity and diameters of glomeruli and hepatocytes), reflecting the resilience of the cells of these organs to acute injuries. Gooneratne et al. (1986) evaluated copper-poisoned sheep and reported that until the onset of hemolysis, renal functions were not altered. In hemolysis, glomerular and tubular damage were proportional to severity. In animals that recovered from hemolysis, renal functions were restored with time. Approximately 3 weeks after the hemolytic crisis, tubular function returned to normal, although glomerular function decreased to $3 / 4$ from the pre-hemolytic value, indicating the presence of residual glomerular damage.
Therefore, in the acute phase of urolithiasis, as in copper intoxication, the renal parenchyma showed high adaptability (resilience) to organ challenges. Howie, Gunson and Sparke (1990) mentioned that although there is consensus on the low correlation between renal excretory function and histological changes in the kidney, especially in acute renal failure and postmortem examination, they have developed an immunohistological method that marks tubule brush edge antigens, mainly from the Henle loop, indicating tubular lesions. They reported that this method was useful and practical in correlating function and structure, which can be used even in the postmortem kidney. 
Most sheep ureters and urinary bladder were unchanged macro- and microscopically. This was also observed by Santarosa et al. (2016), who reported only mild vascular congestion and mononuclear inflammatory infiltrate, characterized by the absence of macroscopic bladder lesions and the nondevelopment of obstructive urolithiasis.

Only one animal presented an ulcerated focal area in the mucous layer due to the aggression caused by bladder distension associated with the presence of uroliths. Farrugia et al. (2006) observed basal urothelium apoptosis in sheep fetuses after 30 days of urethral and urachal obstruction. Additionally, Lu et al. (2017) observed bladder fibrosis in functional or anatomical urinary tract obstructions, reducing bladder storage capacity and emptying ability.

\section{Conclusion}

The formulated feed was effective in inducing clinical disease after 56 days of consumption, demonstrating that the high-grain diet predisposes sheep to the development of urolithiasis, thereby providing a suitable experimental model in future research.

The development of clinical disease after 56 days of consumption demonstrates that high-grain diets, when given for long periods, result in renal lesions that lead to the development of urolithiasis and, therefore, should be used with caution in the feeding of elite sheep. It must be restricted to short periods of time and preferably interspersed with a 70:30 diet (roughage/concentrate).

In acute obstructive urolithiasis in sheep, inflammatory vascular lesions, such as discrete multifocal infiltration of lymphocytes, plasmocytes, and macrophages in the medullar region are observed, associated with multifocal areas from mild to moderate congestion of the glomerular tufts and protein in the tubular lumen in the kidneys. Similarly, in the liver, there is mild to moderate fatty degeneration in the centrolobular regions.

\section{Acknowledgments}

We would like to thank Editage (www. editage.com) for English language editing.

\section{References}

Afonso, J. A. B., \& Guaraná, E. L. S. (2008). Urolitíase em pequenos ruminantes. Jornal do Conselho Regional de Medicina Veterinária de Pernambuco: Veterinária e Zootecnia, v. 1, pp. 7-8.

Aroeira, L. J. M. (1998). Cetose e infiltração gordurosa no fígado em vacas leiteiras. Juiz de Fora: EMBRAPA CNPGL.

Assis, A. C. O., Silva, T. R., Aguiar, G. M. N., Melo, D. B., Almeida, F. C., Medeiros, J. M., \& Nobrega Neto, P. I. (2009). Urolitíase obstrutiva em bovinos no semiárido paraibano. Ciência Animal Brasileira. 1, 4145. doi: 10.5216/cab.v1i0.7711

Assumção, R. F., Pereira-Sampaio, M. A., Sampaio, F. J. B., \& Souza, D. B. (2018). Does a ureteral obstruction affect the contralateral kidney morphology? A stereological analysis in a rodent model. Urologia Internationalis, 100(3), 327-332. doi: 10.1016/j.rvsc.2019.08.001

Belknap, E. B., \& Pugh, D. G. (2002). Diseases of the urinary system. In: D. G. PUGH, Sheep \& goat medicine (pp. 267-271). Philadelphia: Saunders. 
Campos, A. G., Daneze, E. R., Terra Jr, J. A., Barbosa, A. B. R., Sliuzas, G. R. S., Silva, A. A., \& Terra, S. A. (2013). Sonographic morphometry of the liver and biliary tract in porcine models submitted to experimental biliary obstruction. Radiologia Brasileira, 46(2), 89-95. doi: 10.1590/S0100-3984 2013000200012

Dirksen, G., Gründer, H. D., \& Stöber, M. (1993). Rosenberger, exame clínico dos bovinos (3a ed.). Rio de Janeiro: Guanabara Koogan.

Dória, R. G. S., Canola, P. A., Dias, D. P. M., Pereira, R. N., \& Valadão, C. A. A. (2007). Técnicas cirúrgicas para urolitíase obstrutiva em pequenos ruminantes: relato de casos. Arquivo Brasileiro de Medicina Veterinária e Zootecnia, 59(6), 1425-1432. doi: 10. 1590/S0102-09352007000600012

Duarte, C. A., Catellan, J. W., Lucas, F. A., Godoy, G. S., Malheiros, E. B., Oliveira, D., \& Baraldi-Artoni, S. M. (2007). Aspectos morfométricos da cicatrização do cólon descendente de equinos submetidos a enterorrafias aposicionais com poliglactina 910 e com cianoacrilato. Arquivo Brasileiro de Medicina Veterinária e Zootecnia, 59(1), 49-55. doi: 10.1590/ S0102-09352007000100009

Dyce, K. M., Sack, W. O., \& Wensing, C. J. G. (2010). Tratado de anatomia veterinária (4a ed.). Rio de Janeiro: Elsevier.

Faria, L. G., Sampaio, G. R., Campos, I. O., Lacreta, A. C. C., Jr., Varaschin, M. S., Kawamoto, F. Y. K.,... Mesquita, L. R. (2011). Pionefrose decorrente de obstrução ureteral crônica em cão. Anais do Congresso Brasileiro de Medicina Veterinária, Salvador, BA, Brasil, 38.
Farrugia, M. K., Longa, D. A., Godleya, M. L., Peeblesb, D. M., Fryc, C. H., Cuckowa, P. M., \& Woolf, A. S. (2006). Experimental shortterm fetal bladder outflow obstruction: I. Morphology and cell biology associated with urinary flow impairment. Journal of Pediatric Urology, 2(4), 243-253. doi: 10.1016/j. jpurol.2006.01.019

Ferreira,D. O.L.(2009). Avaliação daacidificação urinária em ovinos com a utilização de três tratamentos. Dissertação de mestrado, Faculdade de Medicina Veterinária e Zootecnia, Unesp-Botucatu, SP, Brasil. Recuperado de https://repositorio.unesp. br/handle/11449/89257

Ferreira, D. O. L. (2013). Modelo experimental de urolitíase em ovinos - estudo clínico, laboratorial e hemogasométrico. Tese de doutorado, Faculdade de Medicina Veterinária e Zootecnia, UnespBotucatu, SP, Brasil. Recuperado de https://repositorio.unesp.br/handle/ $11449 / 101283$ ?show=full

Frelier, P. F., Armstrong, D. L., \& Pritchard, J. (1990). Ovine mesangiocapillary glomerulonephritis type I and crescent formation. Veterinary Pathology, 27, 2634. doi: 10.1177/030098589002700104

Garcia-Navarro, C. E. K. (2005). Manual de urinálise veterinária. São Paulo: Varela.

Gooneratne, S. R., Howell, J. McC., \& Aughey, E. (1986). An ultrastructural study of the kidney of normal, copper poisoned and thiomolybdate -treated sheep. Journal of Comparative Pathology, 96(6), 593-612. doi: 10.1016/0021-9975(86)90057-5

Guimarães, J. A., Mendonça, C. L., Guaraná, E. L. S., Dantas, A. C., Costa, N. A., Câmara, A. C. L., Farias, C. C., Afonso, J. A. B. (2012). 
Estudo retrospectivo de 66 casos de urolitíase obstrutiva em ovinos. Pesquisa Veterinária Brasileira, 32(9), 824-830. doi: 10.1590/S0100-736X2012000900002

Hay, L. A., \& Suttle, N. F. (1991). Urolithiasis. In W. B. Martin, \& I. D. Aitken (Eds.), Diseases of sheep (pp. 250-253). Oxford: Blackwell Scientific.

Howie, A. J., Gunson, B. K., \& Sparke, J. (1990). Morphometric correlates of renal excretory function. Journal Pathology, 160(3), 245253. doi: 10.1002 / path. 1711600311

International Committee on Veterinary Gross Anatomical Nomenclature (2017). Nomina anatomica veterinaria. Niteroi, RJ: World Association of Veterinary Anatomists.

Jones, T. C., Hunt, R. D., \& King, N. W. (2000). Patologia veterinária (6a ed.). São Paulo: Manole.

Lima, E. R., Reis, J. C., Menezes, M. M., Santos, F. L., Pereira, M. F., Almeida, E. L.,... Silva, M. G. V. (2009). Aspectos anatomopatológicos em gatos domésticos com doença do trato urinário inferior. Medicina Veterinária, 2(4), 17-26.

Lu, Y. T., Tingskov, S. J., Djurhuus, J. C., Nørregaard, R., \& Olsen, L. H. (2017). Can bladder fibrosis in congenital urinary tract obstruction be reversed? Journal of Pediatric Urology, 13(6), 574-580. doi: 10. 1016/j.jpurol.2017.08.013

Maciel, T. A., Leite, N., Araújo, V. V. Jr., Silva, A. B., Fo., Gomes, D. L. S., Barbosa, A. M. S., \& Oliveira, D. (2016). Avaliação dos perfis minerais séricos, urinários e sedimentares de ovinos recebendo dieta calculogênica. Arquivo Brasileiro de Medicina Veterinaria e Zootecnia, 68(4), 967-976. doi: 10.1590/ 1678-4162-8363
Maciel, T. A., Ramos, I. A., Silva, R. J., Soares, P. C., Carvalho, C. C. D., Souto Maior, R. J., Amoroso, L., Artoni, S. M. B., Afonso, J. A. B., \& Oliveira, D. (2017). Clinical and biochemical profile of obstructive urolithiasis in sheep. Acta Scientiae Veterinariae, 45(1515), 1-15.

Martins, G. S., Martini, A. C., Meirelles, Y. S., Dutra, V., Nespóli, P. E. B., Mendonça, A. J., Torres, M. M., Gaeta, L., Monteiro, G. B., Abreu, J., \& Sousa, V. R. F. (2013). Avaliação clínica, laboratorial e ultrassonográfica de felinos com doença do trato urinário inferior. Semina: Ciências Agrárias, 34(5), 23492356. doi: 10.5433/1679-0359.2013v34n $5 p 2349$

Morais, M. V. (2012). Estudo clínicoepidemiológico da urolitíase obstrutiva em caprinos e ovinos. Dissertação de mestrado, Universidade Federal Rural de Pernambuco, Recife, PE, Brasil. Recuperado de http://www.tede2.ufrpe. br:8080/tede2/handle/tede2/5796

Newman, S. J., Confer, A. W., \& Panciera, R. J. (2009). Sistema urinário. In J. F. Zachary, \& M. D. Mcgavin (Eds.), Bases da patologia em veterinária (4a ed.). Rio de Janeiro: Elsiever.

Ortolani, E. L. (1996). Intoxicação e doenças metabólicas em ovinos: intoxicação cúprica, urolitíase e toxemia da prenhez. In A. G. Silva Sobrinho, A. M. V. Batista, E. R. Siqueira, E. L. Ortolani, I. Susin, J. F. C. Silva,... M. F.S. Borba (Eds.), Nutrição de ovinos (pp. 241-258). Jaboticabal, SP. Funep.

Pagnano, L. O., Baraldi-Artoni, S. M., Pacheco, M. R., Santos, E., Oliveira, D., \& Lui, J. F. (2008). Morfometria de fibroblastos e fibrócitos durante o processo cicatricial 
na pele de coelhos da raça Nova Zelândia Branco tratados com calêndula. Ciência Rural, 38(6), 1662-1666. doi: 10.1590/ S0103-84782 008000600026

Pan, X. L., Wen, Z. S., Zou, X. T., Zhou, E. K., Kou, H. Q., Xu, Z. R., \& Zhang, W. J. (2011). Chemical composition and microstructure of uroliths associated with the feeding of high-level cottonseed meal diet to sheep. Research in Veterinary Science, 91(3), 405-411. doi: 10.1016/j.rvsc.2010.09.00

Pugh, D. G. (2002). Sheep \& goat medicine. Philadelphia, USA: Saunders Company.

Radostits, O. M., Gay, C. C., Hinchcliff, K. W., \& Constable, P. D. (2007). Veterinary medicine: a textbook of diseases of cattle, horses, sheep, pigs, and goats (10nd ed.). Philadelphia: Saunders Elsevier.

Rech, R. R., Rissi, D. R., Rodrigues, A., Pierezan, F., Piazer, J. V. M., Kommers, G. D., \& Barros, C. S. L. (2006). Intoxicação por Solanum fastigiatum (Solanaceae) em bovinos: epidemiologia, sinais clínicos e morfometria das lesões cerebelares. Pesquisa Veterinária Brasileira, 26(3), 183-189. doi: 10.1590/S0100-736X2006 000300010

Riet-Correa, F., Simões, S. D. V., \& Vasconcelos, J. S. (2008). Urolitíase em caprinos e ovinos. Pesquisa Veterinária Brasileira, 28(6), 319-322. doi: 10.1590/S0100-736X 2008000600010

Rossi, R.S.,Bombonato,P.P.,Piva, F.M.,\&Gregory, L. (2012). Avaliação da morfometria renal através do método ultrassonográfico de fêmeas caprinas (Capra hircus) normais da raça Saanen. Pesquisa Veterinária Brasileira, 32(2), 165-173. doi: 10.1590/ S0100-736X2012000200013
Santarosa, B. P., Ferreira, D. O. L., Rodrigues, M. M. P., Dantas, G. N., Sacco, S. R., Lopes, R. S., Dias, A., Gonçalves, R. C. (2016). Avaliação clínica, laboratorial e anatomopatológica do sistema urinário de ovinos confinados com ou sem suplementação de cloreto de amônio. Pesquisa Veterinária Brasileira, 36(1), 1-12. doi: 10.1590/S0100-736X 2016000100001

Statistical Analysis System Institute (2009). SAS: System for windows, Release 6.12. Cary, North Caroline, USA: SAS Institute.

Sisson, S., \& Grossman, J. D. (1986). Getty: anatomia dos animais domésticos (5a ed.). Rio de Janeiro: Guanabara Koogan.

Smith, M. C., \& Sherman, D. M. (1994). Goat medicine. Philadelphia: Lea and Fibeger.

Sousa, A. A. R., Nunes, V. H. S., Oliveira, R. A., Sousa, A. A. S., Teixeira, W. C., \& Coelho, M. C. O. C. (2011). Urolitíase obstrutiva em ovino. Acta Scientiae Veterinariae, 39 (2), 970.

Souza, A. N. M. (2003). Cetose dos bovinos e lipidose hepática. Anais do Seminário (Bioquímica do Tecido Animal), Universidade Federal do Rio Grande do Sul, Programa de Pós-Graduação em Ciências Veterinárias, Porto Alegre, RS, Brasil.

Sun, W. D., Wang, J. Y., Zhang, K. C., \& Wang, X. L. (2010). Study on precipitation of struvite and struvite-K crystal in goats during onset of urolithiasis. Research in Veterinary Science, 88(3), 461-466. doi: 10.1016/j.rvsc.2009.11.010

Tiruneh, R. A. (2006). Ruminant urolithiasis in Ethiopia: alterations of mineral concentrations in bovine urine and sheep 
sera according to the geographic origin or the diet regimen. Reveu Medicine Veterinary, 157(5), 261-164.
Tolosa, E. M. C., Rodrigues, C. J., Behmer, O. A., \& Freitas, A. G., Neto. (2003). Manual de técnicas para histologia normal e patológica (2a ed.). São Paulo: Manole. 